When Walking Fails 
1. The Corporate Practice of Medicine: Competition and Innovation in Health Care, by James C. Robinson

2. Experiencing Politics: A Legislator's Stories of Government and Health, by John E. McDonough

3. Public Health Law: Power, Duty, Restraint, by Lawrence O. Gostin

4. Public Health Law and Ethics: A Reader, edited by Lawrence O. Gostin

5. Big Doctoring: Primary Care in America, by Fitzhugh Mullan

6. Deceit and Denial: The Deadly Politics of Industrial Pollution, by Gerald Markowitz and David Rosner

7. Death Is That Man Taking Names, by Robert A. Burt

8. When Walking Fails: Mobility Problems of Adults with Chronic Conditions, by Lisa I. Iezzoni

9. The Research Imperative: What Price Better Health? by Daniel Callahan 


\section{When Walking Fails}

Mobility Problems of Adults with Chronic Conditions

LISA I. IEZZONI

University of California Press

BERKELEY LOS ANGELES LONDON

The Milbank Memorial Fund

NEW YORK 
The Milbank Memorial Fund is an endowed national foundation that engages in nonpartisan analysis, study, research, and communication on significant issues in health policy. In the Fund's own publications, in reports or books it publishes with other organizations, and in articles it commissions for publication by other organizations, the Fund endeavors to maintain the highest standards for accuracy and fairness. Statements by individual authors, however, do not necessarily reflect the opinions or factual determinations of the Fund.

University of California Press

Berkeley and Los Angeles, California

University of California Press, Ltd.

London, England

(C) 2003 by the Regents of the University of California

Library of Congress Cataloging-in-Publication Data

Iezzoni, Lisa, I.

When walking fails : mobility problems of adults with chronic conditions / Lisa I. Iezzoni

p. ; cm.-(California/Milbank books on health and the public ; 8)

Includes bibliographical references and index.

ISBN 0-520-23742-o (cloth : alk. paper)—ISBN 0-520-23819-2

(paper : alk. paper)

1. Movement disorders. 2. Chronic diseases-

Complications. [DNLM: 1. Movement disorders-United States.

2. Chronic disease-United States. 3. Gait-United States.

4. Movement disorders—psychology—United States. 5. Public policy_United States. WL 390 I22W 2003] I. Title: Mobility problems of adults with chronic conditions. II. Title III. Series.

RC376.5 .I498 2003

$362.4^{\prime} 3^{\prime} 0973-\mathrm{dc} 21$

2002152225

Manufactured in the United States of America
$\begin{array}{llllllllll}12 & 11 & 10 & 09 & 08 & 07 & 06 & 05 & 04 & 03\end{array}$
$\begin{array}{llllllllll}10 & 9 & 8 & 7 & 6 & 5 & 4 & 3 & 2 & 1\end{array}$

The paper used in this publication is both acid-free and totally chlorinefree (TCF). It meets the minimum requirements of ANSI/NISO

Z39.48-1992 (R 1997) (Permanence of Paper). ${ }^{\circledR}$ 
To Reed 
This page intentionally left blank 